\title{
Faces of Postmodern Education. Educational Challenges in a Culture of Participation
}

\section{Dr Monika Miczka-Pajestka}

\author{
Faculty of Pedagogy, \\ The Technical-Humanistic Academy in Bielsko-Biała, Poland \\ E-mail: mmp111@poczta.fm
}

\author{
Doi:10.5901/mjss.2013.v4n11p340
}

\begin{abstract}
The educational processes themselves, as well as images of a teacher in the learning space, constantly change and get modified under the influence of a variety of phenomena taking place in the culture. This mainly applies to institutional activities, supported by various system training models and methods, but also to the direct relationship between a teacher and a student. The article points therefore that such processes occurring at the same time in the culture as: hybridization, fragmentation, multi-culture, virtualization or common life technical improvement comply with so called auto telic education and various forms of non-formal education. There will be undertaken the issue of acquisition of participation in culture competences, and then the attention will be put on educational priorities, adopted within the framework of the European Union, which can be analyzed in a variety of perspectives. However, just like the whole culture, they combine with effects of the so-called "meeting" or "mixing" of various spheres of postmodernism, which is a challenge for a man itself. The article will also attempt to answer, among other, the questions: How does the idea of direct teaching enter it? What challenges appear in the education facing the culture of participation, in the world of complex cultural phenomena? And what are the possibilities and prospects of teaching the Net Society?
\end{abstract}

Keywords: education - post-modernity - challenge - culture of participation

The postmodern transversal awareness allows a human being to participate in many levels or dimensions of human existence as a subject, it means that he is aware of penetration and merging of all elements of this participation, i.e. spheres of common life are connected with scientific knowledge, virtual space, education, religion, spirituality, art, economy, politics, customs and common history etc. This variety of possibilities of "being" in the world favors not only shaping of diverse styles and ways of action, but it also builds or designs varied picture of the post-modern education as the space for clarifying and designing of forms of participation in the culture, and similarly for creating opportunities for acquisition of cultural competences.

Generally, we discuss post-modernity in the frames of the culture of participation, we emphasize a human's opportunities to engage in all socio-cultural spaces, dimensions or spheres. A human being is considered an active subject that involves himself in a range of interactions, independently of a kind or a type of a relation. The issue of participation was already brought up and analyzed in the 1960's and 1970's. On the Polish ground, among others, Andrzej Tyszka defined a human's participation in the culture, considering and emphasizing that it is "every contact of a human with products of the culture, cultural behaviours, and simultaneously direct or indirect contact with other people. This contact bases on the use of products of the culture, on acquisition and reconstruction of values inherent to them, on undergoing current cultural patterns, but also on creating its creators, values as well as behaviours" (Tyszka, 1972, p. 56).

Even then, he pointed at the activity of "being" in the cultural space and taking the projection actions. Nowadays, special attention is being paid to the participation in the culture through multimedia and in multimedia, especially in the convergence of media. And it is connected not only with gaining of receiving competences, but all competences in reading, creating and designing of codes, in plunging oneself in VR and navigation, surfing on the net, which enable to fully engage in the trans-media space connected with learning and applying of new methods, techniques and tools of actions. This also happens in the educational space. Taking into consideration the fact that new technologies stimulate ideas of development and participation in the culture of tomorrow, education, teaching and raising must also undergo these ideas.

The committed participation is clearly visible in educational propositions that are linked with opportunities supplied by M-learning or educational games, Virtual learning VLE and Rapid e-learning, Informal learning and many other types of projects like WebQuest that uses webcasting, blogs and social networks in teaching. It seems important to teachers 
and students to notice in this whole process embraced in it potential and to activate it. Extracting of it to the light and making it present in the socio-cultural life space depends mainly on the subject, on his willingness to engage himself in the process of teaching, learning and self-education. According to Roman Lorens, when considering ways of the use of new technologies in education and problems referring to it, "one can not forget" about the fact that "a human still remains the key element of this system - in both forms as an educated person and an educator" (Lorens, 2011, p. 11). Due to this, the participation or the activity in the culture become the challenge for the subject in the post-modernity, and simultaneously they become the challenge for those who design educational space. It is strongly connected mainly with shaping of the process of education and training in complete participation in the culture, and taking actions in gaining by children, adolescences as well as by adults socio-cultural competences. This process is widely known under the name of the common literacy. It refers to the area of media, and one of the media researcher, Henry Jenkins, in his consideration on the issue of literacy in the scope of the convergence culture, defines media literacy as "the ability to be a rightful participant of the modern media culture" (Jenkins, 2007, p. 251), which should be actualized by every receiver. He emphasized that a human as a subject has not only the right to participate in the culture, but he also has a particular ability to active and multi-aspect, full "being" in the socio-cultural processes and phenomena. According to him, the media themselves allow us to fulfill ourselves in the cultural space, and the extent of these opportunities increases, which forces us to look critically at the processes of education and teaching that perform an important role in opening of the access to the symbolic culture. Leaving of the educational space in too rigid frameworks of teaching and education as well as its bureaucratization give favourable conditions for reduction of this access, what results in selection and exclusion from "the circle of full participation". Furthermore, Jenkins maintains that already mentioned media give great opportunities for the development of this area. Media are something more that applied technologies, they are texts and pictures, ways of thinking and interpretations, forms and places shaping "mixture of all kinds of opportunities for participation" (Jenkins, 2007, p. 249).

One of the elements that create the face of postmodern education is diversely perceived and interpreted in these times idea of university, which is observed among others by Hans-Georg Gadamer, who deliberates over the issue of the organization of new order at the level of higher education. The axis of his considerations is the question about the future of universities, about the innovation in higher education, but without schematization and objectification. He asks: "What the Universitas Literarum in the face of parceling and isolation of departments that is inevitable because of the quantitative growth of institutions really is? (Gadamer, 2008, p. 248). This so-called parceling, as he emphasizes, "leads to collapse of university into vocational schools, less or more tightly isolated from themselves" (Gadamer, 2008, pp. 248249). This indicates the clear internal breakdown of the idea of humanitas, and what follows it coursing of other elements of this structure in different directions. He is convinced that the imminent tearing of a spiritual circle belonging to the university has started (Gadamer, 2008, p. 249).

However, leaving of the academic world on the margin turns out to be also an essential problem. This is marked by H.G. Gadamer in the following question: What happens with the idea of university in the world that among those who roots into it more often cultivates distrust towards the whole way of life of a society and listens to every appeal with lack of trust? In what way the idea of education (Bildung) that supplies participation in researches, which is possibly still something that is genuinely appealing in academic studies, is possible in the reality?" (Gadamer, 2008, p. 249).

Unfortunately, there are no clear answers to these questions nor the one and universal face of the postmodern education, nor even an universal face of a university -or speaking more widely - of higher education. Both, the idea of a university as well as the idea of education from the perspective of post-modernity seem to smear, though we can not ignore some signs of turnabouts in the area of education that head towards the future, in the direction of so- called "education of tomorrow".

H.G. Gadamer, himself, while deliberating on problems connected with higher education and with the perception of the idea of a human's education in general, points out the important cause of this state of things. He blames the way of thinking about a human in general. Therefore, he refers to a very basic and anthropological issue, stating that "We speak about (...) a basic, anthropological issue that is present in all cultures, in all teaching and raising institutions. We speak about the human place in nature. The point is that a human in a specific way- differently from animals - is a social creature, who goes beyond the order of natural drives, the order of instincts and hierarchy according to which the nature's life take place, though we- humans - are undeniably involved in it through the whole process of life" (Gadamer, 2008, p. 251).

H. G. Gadamer highlighted the problem of a human's complexity, its specificity of being a human being and ipso facto a social being, which is strongly connected with a skill at using a language by him, and an ability to keep the distance and suppress his drives or a skill at creating opportunities for common life through institutions, customs and 
laws etc. Simultaneously, it is also connected with a human's ability to socialize. All these create one specific feature, which is pointed out in H.G. Gadamer's work, i.e. "never ending process of learning that finishes with no knowledge at all" (2008, p. 252).

But, is a human being able to meet the challenge? Especially, when theoria, which is a little bit underestimated in the world of practical solutions, despite the fact that according to Gadamer "it should be developed and raised to a higher level by a human", seems to be a problem (Gadamer, 2008, p. 252). Many researchers and analytics of post-modernity notice the occurring and becoming more visible problem of approach of researchers as well as students towards theory, that is being more often separated from the sphere of practice with so-called demarcation line. Meanwhile, theory and practice should have the same importance, and so far it has been the task of universities realizing those earlier mentioned ideas to combine and unite these two areas. However, today, their path has split up. The practical, technical aspect of teaching is being paid attention to, whereas theory is being left in "the another dimension" or just put aside, left alone.

So, it seems essential to find an appropriate criterion of teaching in the world of diversity, multiplicity and intensity of technological development and the convergence of the world of media. We can agree with the statement of JeanFrançois Lyotard that this basic criterion is a human's effectiveness in action-taking, which is visible in teaching system, notably those at the level of higher education (Lyotard, 1997). This refers also to the issue of cognition and understanding of the idea of interdisciplinarity that is promoted mainly in the academic environment and currently put aside in favour of specializations. One may assume after J.-F. Lyotard that if we agree with Humbold's university model, in which every discipline has its own specific place, the idea of interdisciplinarity loses its meaning and can appear only at a speculative level (Compare: 1997, s. 146-147).

Stating that teaching has become somewhat of a subsystem of a social system, J.-F. Lyotard locates the criterion of effectiveness, applied in a particular social system, in teaching. This creates a situation, in which "the purpose of knowledge transfer is no longer the education of elites", but to supply "the system with players who will be able to satisfactorily perform their role on pragmatic positions that are indispensable in many institutions" (1997, p. 136). So, the purposes of higher education may be described as functional. This phenomenon is described by T. Parsons as "the instrumental activism", who emphasizes that the important premise of the culture of the instrumental activism is "the orientation to rational cognition". According to him, this is exactly what creates the basis of the pragmatic society (Parsons, Platt, 1968, p. 507). We may consider it one of the effects of the socio-cultural hybridization, furthermore we may also assume it some kind of an important element of the constantly modifying postmodern trans-cultural order.

Independently on which type of hybridization we choose, the cultural or structural, one of these hybridizations moves to the fore. It is an indication of the phenomenon of "mixing" and "merging" of socio-cultural spaces and simultaneously of shaping and forming new types of identity. This also appears in the sphere of education, especially through merging of some forms - such as already mentioned WebQuest using blogs, social forums, computer games etc. and projects like Theater Virtually created by the laboratory of the Swiss Institute of Technology in Lausanne (EPFL) - into the spheres of teaching and education.

Moreover, the structural hybridization as the one that refers to various, both institutionalized and not, forms of social activity allows to- according to culture researchers such as J. Pieterse or Chris Barker- raise or deepen the scope of a human's participation in diverse "forms of organizations of humans' groups" (Barker, 2005, p. 293).

Such important forms of organizing of humans' groups occurs in the Web. They are mostly fan websites, so-called fan fiction which gather young fans of digital cinema, TV shows, games or science-fiction novels, and specific cartoon characters, movie or television series superheroes. The most important reason for establishing and functioning of such groups is the sense of team spirit and identity of their members that is often strengthened by "common rituals or judging of prepared projects" or "performing of joint rituals" or presenting of "some expert competences" (Jenkins, 2007, s. 83). We may state that communities of fans of for example Star Wars, American Idol, Pulp Fiction, Airwolf, Zorro, The Sims and Harry Potter etc. believe that the unrestricted transfer of information is the fundament of their functioning. The transfer that is beyond all borders (borders of culture, nationality, politics or economy). Such a free communication allows them to enter deeper, immerse themselves into designed worlds and simultaneously strengthen the feeling of "being" a part of this world. It is a crucial aspect of shaping of some patterns in the sphere of the youth culture. Due to this, the specific exchange of thoughts between various media becoming more visible, because all possible stories and interesting characters from books, movies or games start to function in the same space of participation.

This situation, which Jenkins describes as the convergence of media, is connected with the co-existence of different media and the unrestricted flow of information between them, creates favourable conditions for the development of informal education, that is understood according to the earlier mentioned author as the teaching that "takes place 
outside school" embracing "supererogatory and evening classes, learning at home, classes performed at museums and other public institutions, as well as lesser structuralized teaching that happens when we encounter new ideas through contact with informative and entertaining media or in social interactions" (Jenkins, 2007, s. 253).

The free transfer of information and common access to the Internet has raised the value of involuntary teaching as well as learning at a distance (on-line education). This creates new educational challenges for authors of numerous projects of new education or so-called "education of tomorrow".

The process of changes of the ways of media circulation in the sphere of culture and similarly in the area of education happens gradually. This requires considerable deepening of social awareness through increasing of the importance of media education in teaching, for which inter alia Jenkins and participants of American projects promoting the idea of media literacy such as New Media Literacies or The Education Arcade opt.

The mentioned literacy does not deny the user his power, but, what Jenkins also highlights, its role is to making present the thinking about oneself as an active participant of the culture, even as a producer or a creator of some content. This literacy aims at building or forming, especially in children and adolescents' actions, "rich in their meaning relations with media" (Compare: Jenkins, 2007, s. 250) .

Whereas, both convergence as well as hybridization touch the earlier mentioned spheres of education and teaching significantly; and "mixing" of various socio-cultural spheres, spaces and dimensions finds its reflection in pedagogical concepts and theories. We may assume that certain aspects of this hybridism were enclosed in the pedagogical proposition of Gregory Ulmer, which is known as teletheory (Compare: 1989). The teletheory proposed by G. Ulmer is some kind of a reinterpretation of Jacques Derrida's Grammatology. G. Ulmer, himself, emphasizes the fact that the postmodern world created essentially unlimited opportunity for a man to take the advantage of achievements of science, and to use new technologies in everyday life as well as in schools. Due to this, he indicates the necessity of changes in the area of communicative behaviour and of developing of communicative competences. This creates the need for educational reformation through enclosing so-called media literacy in functioning teaching programs. Moreover, he suggests to introduce audiovisual language into every didactic process, considering television techniques very useful for the transfer of knowledge (Ulmer, 1989). In reference to these ideas, we may assume that science, knowledge and education are a particular space for integration of traditional as well as technological elements. And G. Ulmer's idea according to which "learning should be a game written with the use of technique, an audiovisual interaction between public and personal knowledge and technical realization of one's individual $\gg>$ story of life $<<$, understood as history" seems actual and reasonable from the perspective of the post-modernity (Ulmer, 1989, p. 311).

The standpoint of the already mentioned post-modernity researcher, J.-F. Lyotard, seems to be equally important in this discussion. Asking a question about the future of the teacher-student relation, Lyotard points at the tendency, notably visible at universities, to design classes in the frames of system of messages, which may as well be passed by "cyber-professors". Furthermore, he states a little bit ironically that pedagogy, itself, will not suffer because of the new technological transformation, since students should be still taught something, and if not teaching contents then at least how to use terminals (Compare: 1997, s. 142-143).

This is one of the faces of the postmodern education, which is strongly linked with virtualization of reality and commercialization of knowledge, showing essential transformations in the approach and in the ways of acquisition of competences in participation in the culture.

The clear direction of development and the area of challenges for educators, care takers and teachers in the scope of acquisition of cultural competences is determined by members of various network communities, for example modders of games such as Counter-Strike or Half-Life, who seem to be more interested in escaping to the world of digital images and system abilities than in manifesting protest or in putting resistance to what reality offers them. They are an important social group that is often described as a subculture, whose activity and creativity on the Internet seems to be limited only by capabilities and frames of a software.

It seems important to notice that the attitude of young people towards goods, also those virtual, which are present in the surrounding them consumer culture, and similarly their attitude towards the media space, as Paul Willis maintains, is creative. According to him, young people create meanings actively and they are also creative receivers of all what culture gives them in the form of various stories, information as well as commercials, movies and games etc.

Meanwhile, it is worth to pay attention to the fact that communities functioning on the web are tribal in their character, what favours maintaining and developing of new types of interpersonal relations, stimulating social development. And their participants - what is emphasized by Jean Baudrillard- "undergo (...) the same fundamental mechanisms, that rule the whole society. Their anti-sociality is communal, tribal in its character. We can consider them in the frames of McLuhan's category of $>>$ tribalism $<<$ that means global revival, under the auspices of mass media, of the 
oral world and the world basing on touch, the music world and the world of communication (...)"(Baudrillard, 2006, p. 252).

Shaping of this type of spaces and relations, that binds particular individuals in the global arrangement of the world, leads to changes in the approach to participation in common "being" in this world, and simultaneously to changes in education and teaching. Since, many of educational actions are being moved to the Internet space. Contacts between educators/ teachers/lecturers and pupils/students are extended by virtual contacts, e-education and Internet forum meetings or hobby groups meetings. It is a great challenge for authors of educational programs and people designing educational processes, notably at the level of universities.

An important direction of considerations on the issue of the activity of universities and their postmodern functioning was pointed out - back in the 90's - by Prof. Jacques Derrida, who touched the topic of universities' responsibility for the idea of their own independency, and furthermore the responsibility manifesting in tangible resistance against all, appearing in social life, forms of dogmatism (political, ethnic, religious and ideological). During his lecture at the University of Silesia in Katowice, delivered on the occasion of granting him the honorary degree of Doctor honoris causa Universitatis Silesiensis, Prof. Derrida drew attention to the need to take care of critical independency of universities and pointed at the necessity of skilful coming into so-called "Enlightenment of tomorrow", that is a project of the universal rationalism. In his opinion it should be a concern for teaching of tomorrow, a concern - associated with preparation in each of cultivated scientific disciplines- that belongs - as he writes - to well known terms such as: Lumières, Aufklärung and Illuminismo (Derrida, 1997, p.62). Notions that are supposed to refer to various different characters and differently shaped, in the terms of history, cultures. Hence, he proposed and made an appeal to scholars and scientists to create a critical culture and "one universal discipline which would combine all existing ones" (Derrida, 1997, p. 62). It is another face of postmodern education that tries to "give itself a careful consideration" and participates in the critical discourse on knowledge, institutions and post-modernity. In any discourse, especially in these on educational ground, there is an idea of a single entity participating in both, global and the local socio-cultural space. We often talk in discourses about the need for a human's identification and the search for his own identity; therefore, in the view of interaction of many cultures, it arises a large number of problems and questions. It also refers to the sphere of education that embraces institutional activities as well as informal education together with self-education and designing of own life space.

Then, it seems important to pay attention to a subject functioning in a particular space of a class, a school or a university, which can be considered places of assimilation and search for one's identity or of shaping of subjectivity. As it is being pointed out by many researchers of post-modernity, all activities taken in this scope by a subject have forward looking character and many of them associate the above mentioned future with the development of virtual reality. For example, in the terms of Derrick de Kerckhove's theory, the future is linked with the full experience of virtual world, as he says: "give oneself to the experience". This full experience is possible only due to general virtualization, because "we need just to mix tactile interfaces like for example Wii (...) with picture and sound to achieve, sooner or later, "the total record", which enables simulating and stimulating senses of proprioceptive memory (2009, s.82). But, will this "total record" become an expression of a new face of postmodern education? The way to this seems to be very long.

We can conclude that, despite the fact that modernity exceeds anthropocentrism and a human has stopped imitating nature and is no longer completely subordinated to it, we due to our inborn creative aspirations will never become just passive observers of the culture, we will be always its trans-navigating creators and products, and at the same time - acquiring competences- participants. Thus, both a teacher as well a student, a professor and a student are participants of the same way to cognition and experience of the reality, to experience the area of simulation and new forms of communication; and hence they undergo processes of shaping of their own diasporic identities.

\section{References:}

Barker, Ch. (2005), Studia kulturowe. Teoria i praktyka (Eng. Cultural Studies: Theory and Practice), translated by: A. Sadza, Jagiellonian University, Cracow.

Baudrillard, J. (2006), Społeczeństwo konsumpcyjne. Jego mity i struktury (Eng. The Consumer Society: Myths and Structures), Sic!, Warsaw.

de Kerckhove, D. (2009), Przyszłość 2030 (Eng. Future 2030), [in]: Kody McLuhana. Topografia nowych mediów (Eng. McLuhan’s Codes. The Topography of New Media), (ed.). A. Maj, M. Derdy-Nowakowskiego, ExMachina, Katowice.

Gadamer, H.-G. (2008), Teoria, etyka, edukacja. Eseje wybrane (Eng. Theory. Ethics, Education. Selected Essays), (ed.). P. Dybel, selection: R. Godoń, University of Warsaw, Warsaw.

Jacques Derrida. Doctor honoris causa Universitatis Silesiensis, (1997), (ed). B. Malskiej, M. Pogłódek, Katowice.

Jenkins, H. (2007), Kultura konwergencji. Zderzenie starych i nowych mediów (Eng. Convergence Culture: Where Old and New Media Collide) , translated by: M. Bernatowicz, M. Filiciak, Wydawnictwa Akademickie i Profesjonalne, Warsaw. 
Lorens, R. (2011), Nowe technologie w edukacji. (Eng. New Technologies in Education), PWN, Warsaw - Bielsko-Biała.

Lyotard, J-F. (1997), Kondycja ponowoczesna. Raport o stanie wiedzy (Eng. The postmodern Condition: A Report on Knowledge.), translated by: M. Kowalska, J. Migasiński, Fundacja Aletheia, Warsaw.

Parsons, T., Platt, G. M. (1968), Considerations on the American Academic Systems, "Minerva", VI.

Pieterse, J. (1995), Globalization as Hybridization, [in:] Global Modernities, (ed.) M. Featherstone, S. Lash, R. Robertson, London, Newbury Park, CA:Sage.

Tyszka, A. (1972), Uczestnictwo w kulturze (Eng. Participation in Culture), Ossolineum, Warsaw.

Ulmer, G. (1989), Teletheory. Grammatology In the Age of Video, New York \& London. 